\title{
Measuring track density of alpha particles emitted from human teeth and assess of the resulting cancer risk
}

\author{
N. Hassanpour ${ }^{1}$, V. Changizi², M. Gholami ${ }^{*}$ \\ ${ }^{1}$ Department of Radiology and Radiotherapy, Allied Medical Sciences School, Tehran University of Medical Sciences \\ 2Department of Technology of Radiology and Radiotherapy, Allied Medical Sciences School, Tehran University of \\ Medical Sciences \\ ${ }^{3}$ Department of Medical Physics, School of Allied Medical Sciences, Lorestan University of Medical Sciences,
} Khorramabad, Iran

\section{- Original article}

*Corresponding authors:
Mehrdad Gholami, Ph.D.,
E-mail:
$\quad$ Gholami.mehrdad@lums.ac.ir
Revised: August 2020
Accepted: Octeber 2020
Int. J. Radiat. Res., July 2021;
19(3): 607-613
DOI: 10.29252/ijr.19.2.607

\begin{abstract}
Background: Since the radionuclides concentration in teeth is a good indicator of the human body's radioactive contamination, the purpose of this study was to measure the track density of alpha particles emitted from the human teeth and to assess the resulting cancer risk. Material and Methods: In this cross-section study, 93 permanent and unfilled tooth samples were collected from the patients residing in Khorramabad, Iran, and visiting dental clinics in this city. The alpha track density for the tooth samples was measured using CR-39 nuclear track detector. Annual effective dose (AED) and excess lifetime cancer risk (ELCR) were estimated based on the recommendations made by ICRP and UNSCEAR. Results: The mean alpha track density from ${ }^{222} \mathrm{Rn}$ in patients' teeth was 410.15 tracks $\mathrm{cm}^{-2}$, whereas the mean for women and men equaled 441.42 and 378.20 , respectively. This difference was not statistically significant $(P=0.22)$, but there was a statistically significant difference between the track densities in different age groups $(P<0.001)$.In this study, the average radon activity concentration was $40.62 \mathrm{~Bq} \mathrm{~m}^{-3}$. Also, the mean annual effective dose and the mean ELCR were calculated as $1.02 \mathrm{mSvy}^{-1}$ and $3.59 \times 10^{-3}$, respectively. Conclusion: The AED value was higher than the permissible dose limit and also the mean ELCR was higher than the global average. Based on the results, it is necessary to perform periodical monitoring to detect pollution sources.
\end{abstract}

Keywords: Human tooth, alpha particle, cancer risk, CR-39 detector.

\section{INTRODUCTION}

The majority of human radiation exposure originates from natural sources (1). We annually receive some $\mathrm{mSv}$ of these radiations (2). Radioactive isotopes are present in our bodies and the environment. Environmental radioactive contamination can result in human exposure (34). ${ }^{238} \mathrm{U},{ }^{232} \mathrm{Th}$ series, ${ }^{40} \mathrm{~K}$, and their daughters are the main contributors to human internal radiation exposure from natural sources of radioactivity ${ }^{(5)} .{ }^{226} \mathrm{Ra}$ and ${ }^{228} \mathrm{Ra}$ isotopes are the most important radionuclides of ${ }^{238} \mathrm{U}$ and ${ }^{232} \mathrm{Th}$ series, respectively (6). The solubility of ${ }^{226} \mathrm{Ra}$ is higher than ${ }^{238} \mathrm{U}$ (1) and it is considered as the main source of radioactivity in various foods (7). This radioisotope (half-life of 1622 years) emits alpha particle, decays into ${ }^{222} \mathrm{Rn}$ (half-life of 3.8days) [1], and follows the process of calcium metabolism to accumulate in the bones (8). Moreover, $99 \%$ of the human body content of ${ }^{226} \mathrm{Ra}$ is stored in the bones (9). Exposure to high levels of this element in long periods of time can result in death and serious health effects, including anemia, cataract, and cancer (in particular, bone, liver, and breast cancer) (5). 
${ }^{218} \mathrm{Po}$ and ${ }^{214} \mathrm{Po}$ from the Radon series, both of which are alpha-emitters, are the most important agents of the internal radiation to the lungs (10). This type of radionuclide is ingested or inhaled and its half-life determines the radiation exposure to radionuclides in the body (5).

Teeth are developed from skeleton extension (11) and carry the footprint of human changes from the beginning of the first stage to the end of life (12). Biologic crystals including hydroxyapatite $\mathrm{Ca}_{10}\left(\mathrm{PO}_{4}\right)_{6}(\mathrm{OH})_{2}$ form the mineral part of the tooth structure (13). Teeth store radioactive contaminant elements which are bone-seeking, after they enter the body (11). The concentration of radionuclides in the teeth and bones can indicate the rate of radioactive contamination of the body (14-15). There is sufficient evidence to declare alpha-emitting internal radionuclides as carcinogenic and some radionuclides such as radon series are known to be carcinogens in humans (16).

Alpha particles with their dense ionization have higher relative biologic effectiveness than radiations such as $X$ and gamma rays (17). These particles spend all their energy on ionization and can cause chemical and biological changes (18). CR-39 nuclear track detectors are employed in various fields of science and technology such as radon monitoring and alpha identification in order to measure the natural radioactivity of alpha particle in human tissues (19-21). When the detector is exposed to heavy charged particles, such as alpha, comprehensive ionization occurs in its structure and breaks the polymer's chemical bonds. In this way, the permanent footprint of the radiation path remains in the detector structure (22). In the presence of complex fields, only alpha particles are recorded because solid-state nuclear track detectors are completely insensitive to beta particles and gamma rays. The same feature avoids the problem of high background radiation that is encountered in other detectors (23). Accordingly, the present study was aimed to measure the track density of alpha particles emitted from the human teeth and calculate the effective dose and cancer risk based on the recommendations made by ICRP and UNSCEAR organizations.

\section{MATERIALS AND METHODS}

This cross-section study was conducted in the summer of 2018 in Khorramabad, Iran, and was approved by Ethics Committee of Tehran University of Medical Sciences (TUMS), Iran (IR.TUMS.SPH.REC.1397.287).

The alpha track density for the tooth samples was measured using a CR-39 nuclear track detector (PADC Track Analysis Systems Ltd., UK) with the $25 \times 25 \mathrm{~mm}$ area. The study was conducted on 93 permanent and unfilled tooth samples of 47 females and 46 males (the age range of 14-65 years old) collected from dental clinics across Khorramabad. The samples were extracted from the patients with dental diseases or for orthodontic purposes by dentists working in the city clinics. The participants in the present study were non-smokers living in Khorramabad who were born in this city and spent the entire period of their growth and calcification of their teeth there. Sample information, including age, sex, and number of teeth, was recorded by the researcher. Using the method described in the study conducted by Almayahi et al. (2014) (24), the extracted teeth samples were prepared and sterilized in $10 \%$ formaldehyde solution (in order to prevent spoilage of the samples) separately. In order to clean the samples of organic materials and soft tissue, they were washed with a brush and distilled water. Then, they were dried at $100^{\circ} \mathrm{C}$ in the oven for $2 \mathrm{~h}$ (figure 1). In the next step, by making a longitudinal cut, each sample was divided into two halves using a Micromotor set (SDE-SH37L) with dental finishing polishing discs in the dental laboratory. Subsequently, the cutting surface of both halves was placed in contact with both sides of the detector and fixed using adhesive tape and plastic strip. Each sample was placed in a high-density polyethylene bag to prevent the penetration of radon gas and sealed for a period of 115 days in a freezer at $-20^{\circ} \mathrm{C}$ to establish secular equilibrium between radon and its daughters.

At the end of this radiation period, all of the 94 detectors were wrapped in their protective aluminum foils and Zip Kips and, then, delivered 
to Reference Radon Lab, Central Research Laboratory, Mazandaran University of Medical Sciences. In the laboratory, the detectors were etched using method of chemical etching in $\mathrm{NaOH}$ etchant solution $(6.25 \mathrm{M})$ for $3 \mathrm{~h}$ at $85^{\circ} \mathrm{C}$. Afterwards, the number of alpha particle tracks per unit area of the detector was counted by an automatic alpha particle counter system equipped with a mechanical and electronic system, controlled entirely by a computer. The counting system took 30 microscope images from each CR-39 film and the number of alpha particles (tracks) was then changed to radon concentration in Bq. ${ }^{3}$ using calibration and conversion factors (the calibration factors of the detectors were previously determined by Atomic Energy Organization of Iran).

The radioactivity concentration of radon-222 (C) was calculated by equation 1 :

$\mathrm{C}\left(\mathrm{Bq} \mathrm{m}^{-3}\right)=\left(\rho-\rho_{\mathrm{b}}\right) / \mathrm{kt}$

Where $\rho$ and $\rho_{b}$ are the number of alpha tracks of the samples (track $\mathrm{cm}^{-2}$ ) and the number of background tracks in the CR-39 detector, respectively, $\mathrm{k}$ is the conversion coefficient of 0.0878 track $\mathrm{cm}^{-2} \mathrm{~Bq}^{-1}$ day $^{-1} \mathrm{~m}^{3}$ used to convert alpha track density into radon radioactivity concentration, and $t$ is the exposure time (days). The background track density analysis was performed on a blank detector stored alone.

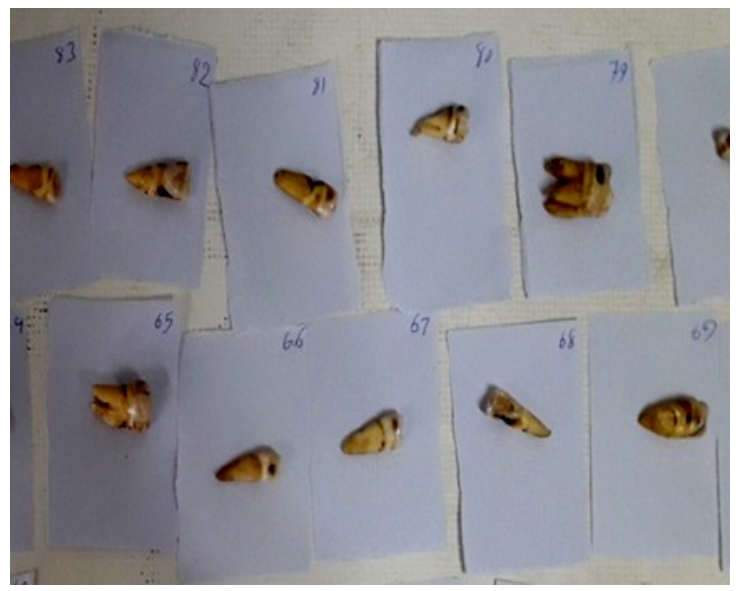

Figure 1. Samples dried at $100^{\circ} \mathrm{C}$ for $2 \mathrm{~h}$.

In this study, the annual effective dose (AED) was calculated by equation 2 (25):
$\operatorname{AED}\left(\mathrm{mSvy}^{-1}\right)=\mathrm{C} \times \mathrm{F} \times 0 \times \mathrm{T} \times \mathrm{DCF}$

where $\mathrm{C}$ is the radon radioactivity concentration, $\mathrm{F}$ is the $\mathrm{Rn}-222$ equilibrium factor indoors recommended to be $0.4,0$ is the indoor occupancy factor $(0.8), \mathrm{T}$ is the indoor occupancy time $(8760 \mathrm{hr} / \mathrm{yr})$, and DCF is the dose conversion factor recommended to be $9 \times 10^{-6} \mathrm{mSvh}^{-1}\left(\mathrm{Bqm}^{-3}\right)^{-1}$ by UNSCEAR ${ }^{(26)}$.

In the next step, the excess lifetime cancer risk (ELCR) was estimated using equation 3, as follows (27):

$\mathrm{ELCR}=\mathrm{AED} \times \mathrm{DL} \times \mathrm{RF}$

in which AED denotes the annual effective dose, DL represents the duration of life $(70$ years), and RF indicates the fatal cancer risk factor $\left(0.05 \mathrm{~Sv}^{-1}\right.$ for public exposure).

\section{Statistical analysis}

Analytical and descriptive statistics was performed in SPSS software (ver.25); SPSS Inc, Chicago, USA).

\section{RESULTS}

The alpha track density in the tooth samples was determined (figure 2). The mean background alpha track density at different points of the detector equaled 52.31 track $\mathrm{cm}^{-2}$ in this study. Furthermore, the mean alpha track density in the samples was $410.15 \pm 248.98$ track $\mathrm{cm}^{-2}$, as presented in table 1 .

The average alpha track density in the female teeth was $441.42 \pm 276.29$ track $\mathrm{cm}^{-2}$, whereas it was378.20 \pm 215.95 track $\mathrm{cm}^{-2}$ in the male teeth, as demonstrated in table 2 . This difference was not statistically significant $(\mathrm{P}=0.22)$. A similar result for excess lifetime cancer risk was obtained because a linear relationship existed between alpha track density, radioactivity concentration of radon, annual effective dose, and excess lifetime cancer risk.

The results in Table 3 illustrate statistically significant differences between the mean alpha track density in the age groups $(\mathrm{P}<0.001)$. The 
mean alpha track density was observed to be minimum $\left(235.06 \pm 91.42\right.$ track $\left.\mathrm{cm}^{-2}\right)$ for the donors aged 50 years old and above.

A similar result was obtained for the radioactivity concentration of radon, annual effective dose, and excess lifetime cancer risk because a linear relationship existed between alpha track density and these variables.

In the female donors aged $<30$ years old, the alpha track density values were observed to be statistically significantly lower than those of the

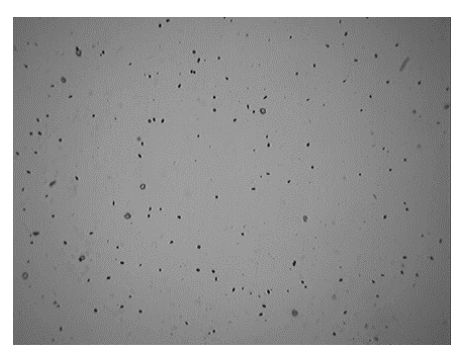

Figure 2. Alpha track density on CR-39 of a typical tooth sample. 30-49-year-oldage group $(\mathrm{P}=0.03)$ figure 3).Furthermore, in the male donors aged $<30$ years old, the alpha track density values were observed to be statistically significantly higher than those of the female donors of the same age $(\mathrm{P}=0.01)$.

In the male subjects aged 50 years old and above, the alpha track density values were observed to be lower than those of the other age groups $(\mathrm{P}<0.001)$.

Table 1. The Alpha Track Density Emitted from Human Teeth and the Resulting Excess Lifetime Cancer Risk

\begin{tabular}{|c|c|}
\hline & Mean \pm SD \\
\hline Alpha track density $\left(\right.$ track $\left.\mathrm{cm}^{-2}\right)$ & $410.15 \pm 248.98$ \\
\hline $\begin{array}{c}\text { Radioactivity concentration of } \\
\text { radon-222 }\left(\mathrm{Bq} \mathrm{m}^{-3}\right)\end{array}$ & $40.62 \pm 24.65$ \\
\hline Annual effective dose $\left(\mathrm{mSvy}^{-1}\right)$ & $1.02 \pm 0.62$ \\
\hline Excess lifetime cancer risk $\times 10^{-3}$ & $3.59 \pm 2.18$ \\
\hline
\end{tabular}

Table 2. Results of alpha track density and excess lifetime cancer risk by gender.

\begin{tabular}{|c|c|c|c|}
\hline \multirow{2}{*}{} & \multicolumn{2}{|c|}{ Gender } & \multirow{2}{*}{ P-value } \\
\cline { 2 - 3 } & Female & Male & \\
\cline { 2 - 3 } & Mean \pm SD & Mean \pm SD & \\
\hline Alpha track density $\left(\right.$ track cm $\left.{ }^{-2}\right)$ & $441.42 \pm 276.29$ & $378.20 \pm 215.95$ & 0.223 \\
\hline Radioactivity concentration of radon-222 $\left(\mathrm{Bq} \mathrm{m}^{-3}\right)$ & $43.71 \pm 27.36$ & $37.45 \pm 21.38$ & 0.222 \\
\hline Annual effective dose $\left(\mathrm{mSvy}^{-1}\right)$ & $1.10 \pm 0.69$ & $0.94 \pm 0.54$ & 0.222 \\
\hline Excess lifetime cancer risk $\times 10^{-3}$ & $3.86 \pm 2.42$ & $3.31 \pm 1.89$ & 0.222 \\
\hline
\end{tabular}

Table 3. Results of Alpha Track Density and Excess Lifetime Cancer Risk by Age.

\begin{tabular}{|c|c|c|c|c|}
\hline & \multicolumn{3}{|c|}{ Age category } & \multirow[b]{2}{*}{ P-value } \\
\hline & $\begin{array}{c}<30 \\
\text { Mean } \pm \text { SD }\end{array}$ & $\begin{array}{c}30-49 \\
\text { Mean } \pm S D\end{array}$ & $\begin{array}{c}\geq 50 \\
\text { Mean } \pm \text { SD }\end{array}$ & \\
\hline Alpha track density (track $\mathrm{cm}^{-2}$ ) & $459.65 a \pm 275.57$ & $486.99_{a} \pm 245.14$ & $235.06_{b} \pm 91.42$ & $<0.001$ \\
\hline $\begin{array}{l}\text { Radioactivity concentration of } \\
\text { radon-222 }\left(\mathrm{Bq} \mathrm{m}^{-3}\right)\end{array}$ & $45.52_{a} \pm 27.29$ & $48.22_{\mathrm{a}} \pm 24.27$ & $23.28_{b} \pm 9.05$ & $<0.001$ \\
\hline Annual effective dose $\left(\mathrm{mSvy}^{-1}\right)$ & $1.15_{a} \pm 0.69$ & $1.22_{a} \pm 0.61$ & $0.59_{b} \pm 0.23$ & $<0.001$ \\
\hline Excess lifetime cancer risk $\times 10^{-3}$ & $4.02_{a} \pm 2.41$ & $4.26 \mathrm{a} \pm 2.14$ & $2.06_{b} \pm 0.80$ & $<0.001$ \\
\hline
\end{tabular}

$\mathrm{a}, \mathrm{b}$ : Values in the same row and sub-table not sharing the same subscript are significantly different at $\mathrm{P}<0.05$ in the two-sided test of equality for column means.

Table 4. Analysis of variance results of the alpha track density for age groups.

\begin{tabular}{|c|c|c|c|c|c|}
\hline $\begin{array}{c}\text { Source of } \\
\text { variation }\end{array}$ & $\begin{array}{c}\text { Sum of } \\
\text { Squares }\end{array}$ & $\begin{array}{c}\text { Degrees of } \\
\text { freedom }\end{array}$ & $\begin{array}{c}\text { Mean } \\
\text { Square }\end{array}$ & F ratio & p-value \\
\hline Between Groups & 1060798.411 & 2 & 530399.205 & 10.283 & $<0.001$ \\
\hline Within Groups & 4642167.186 & 90 & 51579.635 & & \\
\hline Total & 5702965.597 & 92 & & & \\
\hline
\end{tabular}




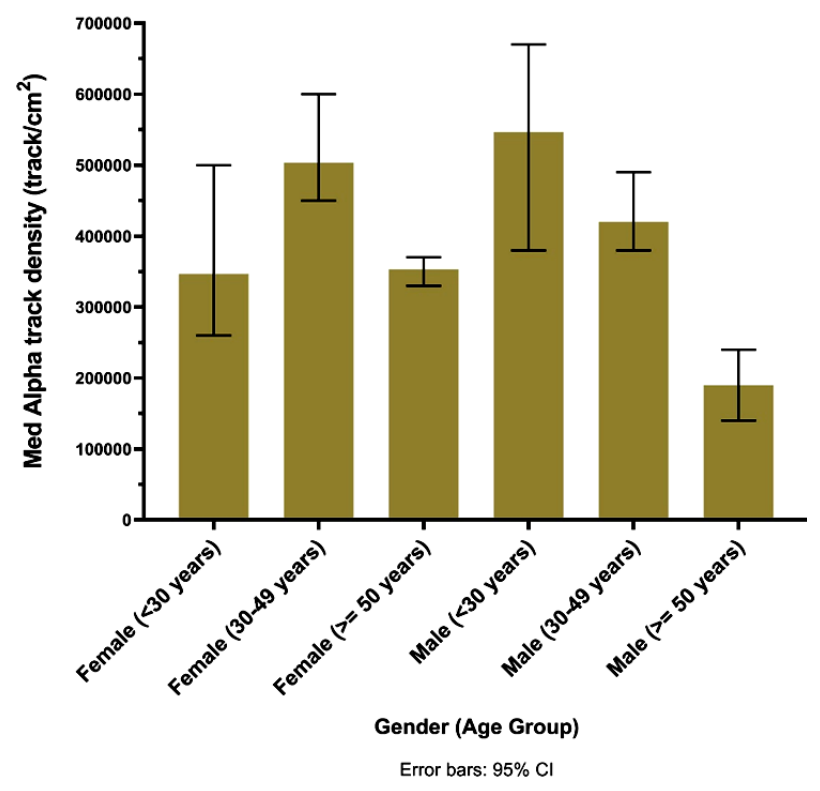

Figure 3. Alpha track density versus gender and age group.

\section{DISCUSSION}

${ }^{226} \mathrm{Ra}$ and ${ }^{222} \mathrm{Rn}$ (from the ${ }^{238 \mathrm{U}}$ decay chain) and ${ }^{228} \mathrm{Ra}$ (from the ${ }^{232} \mathrm{Th}$ decay chain) have demonstrated a greater effect than other radionuclides on the human health (28). Radioactive substances transmitted into the body can accumulate in certain parts and cause internal radiation exposure (29). Therefore, it is of great importance to monitor the presence of radionuclides in some human tissues and organs (30).

In the present investigation, the mean radioactivity concentration of ${ }^{222} \mathrm{Rn}$ was estimated to be $40.62 \mathrm{~Bq} \mathrm{~m}^{-3}$ which was lower than the reference level $\left(100-300 \mathrm{Bqm}^{-3}\right)$ recommended by ICRP (31). Based on table 1 , the calculated value of mean annual effective dose was below the global average of $1.15 \mathrm{mSvy}^{-1(2)}$ and mean ELCR wasapproximately 2.47 times higher than the global average of $1.45 \times 10^{-3}$ (26).

Based on our results, the mean alpha track density in the samples was $410.15 \pm 248.98$ track $\mathrm{cm}^{-2}$. In the study in Malaysia, Almayahi et al. used CR-39 and found the mean alpha track

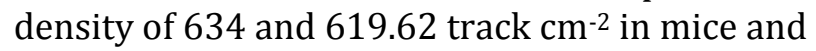
chicken bones, respectively [32]. In another study, Almayahi et al. found the mean alpha track density of 153 and 544 track cm-2in the human teeth and animal bones, respectively (24); in tooth samples, it was about 2.6 times lower than what we found in the present study. Furthermore, Almayahi et al. measured the average alpha track density in the human teeth in Iraq, which equaled 489.9 track $\mathrm{cm}^{-2(33)}$ and was higher than the findings reported in our work.

It was found that there is no significant effect for sex on the mean alpha track density in the human teeth. However, the mean alpha track density in the male teeth was slightly lower than that in the female teeth. This difference may be due to dietary habits and interactions with the environment. In contrast, Almayahi et al. found that sex had no significant effect on the alpha emission rates in the extracted human teeth (32). Similar to the results obtained in the present investigation, in another study by Almayahi et al., the mean alpha emission rates in the male teeth were slightly higher than those in the female teeth; but, the difference was not statistically considerable (24).The findings of the study by Gholizade etal. demonstrated no considerable difference between the radioactivity concentration of $210 \mathrm{PO}$, an alpha-emitting radionuclide from the ${ }^{238} \mathrm{U}$ decay chain, in female and male teeth ${ }^{34)}$.On the other hand, Task et al. found that the gross alpha radioactivity level was higher in the male donors' tooth samples than those of the female donors (30).

In this study, the mean alpha track density was observed to be minimumfor the donors aged 50 years old and above. This can be the result for the decline in skeletal growth in this age, as the site of the body where alpha-emitter elements are stored. Osteoporosis and bone fractures are among the most prevalent geriatric syndromes, the risk of whichincreases with age (35-37). In contrast to our observations, Almayahi et al. found no statistically significant difference between alpha emission rates in the age groups (24). In the study conducted by Taskin etal., a slight decline was reported in the gross alpha level for male and female donors over the age of 45 years old (30). In another study, gross alpha activity concentrations were found and compared to changes in calcium in the human teeth. Based on the results, the gross alpha activity concentrations had different amounts for 
those under and over 18 years of age (38).

Relatively similar to the results obtained in the present investigation, Taskin et al. reported that in the female donors' in the 19- to 30-yearold age category, the average levels of gross alpha radioactivity were lower than those of the other age categories (30). This can be explained by the fertility age of females $(38,39)$ and their physiological and hormonal conditions (30) during this period because the amount of calcium, which has a direct relationship with alpha particles, significantly declines in women during their fertility period (39-40). Furthermore, in the study by Omer et al., the amount of Ca had an increase in the 19- to 25-year-old males, while there was a decline in females of the same age group. In addition, there was an increase in female donors aged over 19-25 years old (38).

\section{CONCLUSION}

Based on the findings obtained here, the mean annual effective dose was higher than the global average and also the mean ELCR was approximately 2.47 times higher than the global average. Therefore, it is necessary to perform periodical monitoring to detect pollution sources. Moreover, sex was found to have no significant effect on the mean alpha track density in human teeth, but mean alpha track density differed for different age groups.

\section{Conflicts of interest: Declared none.}

\section{REFERENCES}

1. Aghamiri SM, Ghorbani Z, Darafsheh A, Torabzadeh $H$, Fathivand AA, Minuchehr A, Jalinoos A(2006) 226Ra concentration in the teeth of habitants of areas with high level of natural radioactivity in Ramsar. Journal of Environmental Radioactivity, 89(3): 212-218.

2. United Nations United Nations Scientific Committee on the Effects of Atomic Radiation: UNSCEAR (2008) Sources and Effects of lonizing Radiation.

3. Eisenbud M and Gesell TF (1997) Environmental radioactivity from natural, industrial and military sources: from natural, industrial and military sources. Elsevier.
4. Henriksen T, Maillie HD, Korchin SR (2003) Radiation and health. Medical Physics, 30(10):2857.

5. Almayahi BA (2016) Biomarkers of Natural Radionuclides in the Bone and Teeth: Biomarkers in Disease: Methods, Discoveries, and Applications. Biomarkers in Bone Disease, 1-21.

6. Dewit T, Clulow V, Jackson JS, Mitchel RE (2001) Uranium and uranium decay series radionuclide dynamics in bone of rats following chronic uranium ore dust inhalation. Health physics, 81(5): 502-513.

7. Singh J, Singh H, Singh S, Bajwa BS (2009) Uranium, radium and radon exhalation studies in some soil samples using plastic track detectors. Indian Journal of Physics, 83(8): 1147-1153.

8. Shakir Khan M., Naqvi A.H., Azam A., Srivastava D.S (2011) Radium and Radon Exhalation Studies of Soil. International Journal of Radiation Research, 8(4): 207-210.

9. ICRP Committee II (1959) Report of Committee II on permissible dose of internal radiation. Health Phys, 3: 217-26.

10. Tirmarche $M$, Harrison JD, Laurier $D$, Paquet $F$, Blanchardon E, Marsh JW (2010) Lung cancer risk from radon and progeny and statement on radon. Ann ICRP, 40(1): 1-64.

11. Samuels LD (1966) Uptake of radium-226 from drinking water into human deciduous teeth. Archives of Oral Biology, 11(6): 581-586.

12. Dewit T, Clulow V, Jackson JS, Mitchel REJ (2001) Uranium and uranium decay series radionuclide dynamics in bone of rats following chronic uranium ore dust inhalation. Health Physics, 81(5): 502-513.

13. Nanci A (2003) Ten Cate's oral histology development, structure, and function. Pp. 192-239.

14. Carvalho M L, Casaca C, Pinheiro T, Marques J P, Chevallier P, Cunha A S (2000) Analysis of human teeth and bones from the chalcolithic period by X-ray spectrometry. Nuclear Instruments and Methods in Physics Research Section B: Beam Interactions with Materials and Atoms, 168(4): 559-565.

15. Gomes V E, De Sousa M D L R, Barbosa JrJr F, Krug F J, Saraiva M D C P, Cury J A, Gerlach R F (2004) In-vivo studies on lead content of deciduous teeth superficial enamel of preschool children. Science of the Total Environment, 320(1): 25-35.

16. International Agency for Research on Cancer (2009) A review of human carcinogens, Part D: radiation, 100.

17. International Commission on Radiological Protection (1991) Recommendations of the International Commission on Radiological Protection. ICRP Publication 60. Ann ICRP, 21(1-3): 1-201.

18. Christensen DM, Livingston GK, Sugarman SL, Parillo SJ, Glassman ES (2014) Management of ionizing radiation injuries and illnesses, part 3: radiobiology and health effects of ionizing radiation. The Journal of the American Osteopathic Association, 114(7): 556-565.

19. Henshaw DL (1989) Application of solid state nuclear track detectors to measurements of natural alpha-radioactivity in human body tissues. International Journal of Radiation Applications and Instrumentation. Part D. Nuclear Tracks 
and Radiation Measurements, 16(4): 253-270.

20. Henshaw DL, Allen JE, Keitch PA, Randle PH (1994) Spatial distribution of naturally occurring 210Po and 226Ra in children's teeth. Int J Radiat Biol, 66(6): 815-826.

21. Joshirao PM, Shin JW, Hong SW, Kolekar RV, Manchanda VK (2015) Geometrical parameters of tracks registered by collimated alpha particles on CR-39 detector. Nuclear Instruments and Methods in Physics Research Section B: Beam Interactions with Materials and Atoms, 351: 56-60.

22. El Ghazaly M and Hassan HE (2014) Spectroscopic studies on alpha particle-irradiated PADC (CR-39 detector). Results in Physics, 4: 40-43.

23. Zaki MF, El-Shaer YH (2007) Particularization of alpha contamination using CR-39 track detectors. Pramana, 69(4): 567-574.

24. Almayahi BA, Tajuddin AA, Jaafar MS (2014) Radiobiological long-term accumulation of environmental alpha radioactivity in extracted human teeth and animal bones in Malaysia. Journal of Environmental Radioactivity, 129: 140 $-147$.

25. ICRP. International Commission on Radiological Protection (1993) Protection against Radon-222 at home and at work. ICRP Publication 65. Ann. ICRP. Pergamon Press, Oxford, 23(2).

26. Qureshi AA, Tariq S, Din KU, Manzoor S, Calligaris C, Waheed A (2014) Evaluation of excessive lifetime cancer risk due to natural radioactivity in the rivers sediments of Northern Pakistan. Journal of Radiation Research and Applied Sciences, 7(4): 438-447.

27. ICRP. International Commission on Radiological Protection (1990) Recommendations of the Commission. ICRP Publication 60. Pergamon, Oxford, 21: 1-3.

28. Piroozfar P (2007) Study of natural radionuclides of water and sediment in Tehran 1: 100000 map, Twenty fifth assembly of Geological Sciences, Tehran, Iran.

29. Onishchenko A, Zhukovsky M, Veselinovic N, Zunic ZS (2010) Radium-226 concentration in spring water sampled in high radon regions. Applied Radiation and Isotopes, 68 (4-5): 825-827.

30. Taşkin $H$, Kobya $Y$, Tokgöz $M$, Başsari A, Yeşilkanat CM (2018) Biomonitoring of trace elements and gross alpha/ beta radioactivity levels in human teeth: A case study from Istanbul, Turkey. Microchemical Journal, 141: 458-465.

31. Lecomte JF, Solomon S, Takala J, Jung T, Strand $P$, Murith C, Kiselev S, Zhuo W, Shannoun F, Janssens A (2014) ICRP Publication 126: Radiological Protection against Radon Exposure. Annals of the ICRP, 43(3): 5-73.

32. Almayahi BA, Tajuddin AA, Jaafar MS (2012) Measurements of alpha emission rates in bones using CR-39 track detector. Nucl Tracks Radiat Meas, 16: 253-270.

33. Almayahi BA (2017) Determination of Radionuclide Concentration in Human Teeth in Najaf Governorate, Iraq. Iran J Medica Physics, 14(4): 173-182.

34. Gholizade Rad S, Vahabi Moghaddam M, Hosseini T, Barati H, Fattahi E (2010) Measurement of 210Po in Iranian smokers' and non-smokers' teeth. Radiation Protection Dosimetry, 138(4): 389-392.

35. Batsis JA, Mackenzie TA, Lopez-Jimenez F, Bartels SJ (2015) Sarcopenia, sarcopenic obesity, and functional impairments in older adults: National Health and Nutrition Examination Surveys 1999-2004. Nutrition Research, 35(12): 1031-1039.

36. Wright NC, Looker AC, Saag KG, Curtis JR, Delzell ES, Randall S, Dawson-Hughes B (2014) The recent prevalence of osteoporosis and low bone mass in the United States based on bone mineral density at the femoral neck or lumbar spine. Journal of Bone and Mineral Research, 29 (11): 2520-2526.

37. Burns ER, Stevens JA, Lee R (2016) The direct costs of fatal and non-fatal falls among older adults-United States. Journal of Safety Research, 58: 99-103.

38. Söğüt Ö, Aydın MF, Küçükönder $E$, Zorer ÖS, Doğru M (2010) Measurement of gross alpha and gross beta activity concentrations in human tooth. Journal of Environmental Radioactivity, 101(3): 226-229.

39. Aydın, M.F (2009) Systematic Analysis of the Human Tooth, MSc Thesis, Kahramanmaras, Sutçu Imam University, Kahramanmaras, Turkey.

40. Barger MK (2010) Maternal nutrition and perinatal outcomes. Journal of Midwifery \& Women's Health, 55(6): 502-511. 
